\title{
CD79B Gene Mutation
}

National Cancer Institute

\section{Source}

National Cancer Institute. CD79B Gene Mutation. NCI Thesaurus. Code C148390.

A change in the nucleotide sequence of the CD79B gene. 